Rasyiid, Maulina, Resueňo, Nasrullah, and Rusli.

Tell: Teaching of English Language and Literature Journal

Vol. 9, No.2, September 2021, Doi: http://dx.doi.org/10.30651/tell.v9i2.9482

\title{
Instagram Usage in Learning English: A Literature Review
}

\author{
Rizal Nur Rasyiid \\ Universitas Muhammadiyah Kendari, Indonesia \\ nurrasyiidrizal@gmail.com \\ Maulina Maulina* \\ Universitas Muhammadiyah Kendari, Indonesia \\ maulina@umkendari.ac.id \\ *corresponding author \\ Celso P. Resueňo \\ Nueva Ecija University of Science and Technology, Philippines \\ rcelso72@yahoo.com \\ Rahmat Nasrullah \\ UniversitasMuhammadiyahKendari, Indonesia \\ rahmat.nasrullah@umkendari.ac.id \\ Tri Indah Rusli \\ Universitas Muhammadiyah Kendari, Indonesia \\ tri.indahrusli@umkendari.ac.id
}

\section{Article History}

Received: 16 August 2021

Reviewed: 25 August 2021

Accepted: 14 September 2021

Published: 30 September 2021

\section{Highlights}

Social media of Instagram plays an important role in daily life communication and interaction also pledge a myriad potential learning to develop students' English skills.

\begin{abstract}
The social media of Instagram, one of the most used platforms to connect online, is used to build relations and correlations among individuals to support long-distance interaction. Educators and researchers often apply it in global contexts for educational purposes like the teaching and researching English learning using Instagram. This study presents an analysis of Instagram usage in daily life also its usage in the English learning development with strengths and weaknesses reviews. Authors gathered data from reviewing trustworthy articles sources like Research Gate, Turkish Online Journal of Educational Technology, Arab International English Journal, Springer link, Atlantis press, and Science Direct.
\end{abstract}

Keywords: English skills, Instagram, learning English, long-distan interaction, social media

\section{Introduction}

In this modern era, almost every human works of life are possessed by technology. For instance, in socializing issues, many platforms can be used to instantly gain information from society, known as social media. Social media platforms enable people to stay flexible to communicate, connect, and interact in this digital era (Maulina et al., 2019; Maulina et al., 2020; Maulina et al., 2021; Saputra et al., 2021). Instagram originally is one of the social media that allows users to share, upload, and search amount of photos and short videos. Although it is a social media, Instagram has enormous potential to become an alternative learning tool. Stojanovíc et al. (2019) showed good numbers of results which could assume 
Rasyiid, Maulina, Resueňo, Nasrullah, and Rusli.

Tell: Teaching of English Language and Literature Journal

Vol. 9, No.2, September 2021, Doi: http://dx.doi.org/10.30651/tell.v9i2.9482

Instagram as a fabulous learning tool. It creates an exciting learning environment as well as attractiveness and extraordinary learning experience.

Further, Sesriani and Sukmawati (2019) asserted that Instagram is recommended to utilize in order to learn English. It is because Instagram can motivate the learners to become active in speaking and, Instagram highly needs to develop due to its advantages and positive result as a potential digital learning tool. Nevertheless, in some places, Instagram is rarely used for learning purposes, although frequent in some cases revealed positive impact on learner's achievement scores (Elarsan, 2019).

On the other hand, many researchers had finished studying Instagram as an English learning tool and figured out its effect on learners' English skills. For example, Akhiar et al. (2017) did research focusing on learners' attitudes and perception toward Instagram and learners' English skills. As a result, it proved a high positive impact affect the learners writing skills. Afifah et al. (2019) did similar research but different English skills, namely speaking. This research showed how the learners gradually become good at speaking. Learners obtain self-confidence to bring up their idea and keep motivated in learning speaking. It happens because this learning method is emphasizing the students to stay active and unconsciously braver. Besides, in a journal entitled Instagram application: An active tool in cultivating reading behavior, Morshidi et al. (2019), at the same time, study whether Instagram is effective in cleaning up learners reading skills and keep them sticking to the subject. The effect of cultivating is that the students become more active and cooperative during the teaching-learning process. Through Instagram, most of the students can slowly drill their reading skills alongside understanding the material. Eventually, it indicated Instagram's success in cultivating reading behavior among the learners and indicates a splendid positive impact.

Besides, vocabulary is an absolute term that must be insignificant because it is fundamental to English skills. In addition, vocabulary covers all English skills such as Speaking, Writing, Reading, and listening. Also, there are lots of researchers who linked in. For example, (Richards \&Renadya, 2002, as cited in Asyiah, 2017), vocabulary plays a crucial part in foreign language learning and wrap in speaking, writing, reading, and listening. Further, (Setiawan 2010, as cited in Asyiah, 2017) stated that vocabulary concerns receptive and productive knowledge. To sum up, Instagram usage must be examined further due to its potential in the educational field, particularly in learning vocabulary.

\section{Instagram Usage in Daily Life}

Commonly, Instagram does not create as a genuine learning media instead for interaction purposes. In addition, in the beginning, Instagram just insisted on enabling the users to share photos and videos, either publicly or privately, with another for entertainment. Therefore, many individuals aimed to develop it and drill into new purposes like business and marketing, education, also other fields. Alkhowaiter (2016) found various contentions for Instagram's benefit as business and marketing by saying Instagram is very practicing because it can run the store from home. Besides, it can present local and global marketing at once and procure various customers.

Furthermore, the 'comment and tagging feature' eases the seller in identifying the follower's needs and fulfill them (paras. 1-3). Therefore, in line with Ahmadinejad and Alsi (2017), Instagram is surely recommended to assist E-marketing. They stated, "compared to traditional marketing methods that are expensive and time time-consuming modern methods such as social media marketing, that can be considered as an e-mouth marketing, companies can in a shorter time and with less investment, create amazing result" (Ahmadinejad\&Asli, 2017, p. 96). 
Rasyiid, Maulina, Resueňo, Nasrullah, and Rusli.

Tell: Teaching of English Language and Literature Journal

Vol. 9, No.2, September 2021, Doi: http://dx.doi.org/10.30651/tell.v9i2.9482

In education case, Instagram is decent to be teaching and learning instrument. With it, learners could find out several accounts related to their needs. For example, to enhance Microsoft Word insight for framing scientific writing, the college students must be looking for in Instagram search option and follow the page provided like zonamahasiswa.id and watch about tips and tricks to ease doing excellent structured writing. Moreover, in English learners' case, they can do the same way and search various pages about English based on their level. Also, teacher and teaching training college students could enrich their insight through educational pages related to teaching approach, method, strategy, and teaching media. Thus, it could not be denied that Instagram is appropriate in the education field. Also, with Instagram, learners can improve their skills and build a brilliant way to the future, allow the learners to arrange their notions with relevant and contextual content, applicable to maintaining learners motivations to learning because it is enjoyable, fascinating, innovative, and adequate to support success teaching-learning process (Handayani, 2016; Pujiati et al., 2019; RomeroRodriguez et al., 2020; Yudhiantara \& Nuryantini, 2018).

\section{Instagram Usage toward English Skill Development}

\section{a. Speaking}

Speaking is one English skill that intends to bridge each other and enable speakers to communicate directly. Speaking discusses the way the speakers deliver their thought, idea, opinion, contention, and assumption orally through producing, receiving, and processing information. Besides, Instagram could support speakers to do exercises to improve their speaking skills. Through Instagram, they can create short videos like tutorial videos or long videos like a live broadcast, public speaking, or vlog video likewise. For instance, the speakers can imitate how others speak, make a similar video, and upload it on Insta-story. Through this method, the speakers can observe what make the difference between their video, and also this method can slightly reduce anxiety in speech because the speaker is gradually accustomed to speaking even just virtually.

It is in line with a study done by several researchers, namely DifianiApriyanti, Syofiani, SyahrulRamadhan, and Mukhaiyar, from some different universities in Indonesia and they work for a splendid journal. They intend to find out how Instagram can improving student's public speaking. Furthermore, they evaluate some categories of public speaking like content organizing and speech techniques (e.g., speech explication, word choice, and vocal organizing). As a result, Apriyanti et al. (2018) found that Instagram successfully shapes the students. For example, both speaking skills or student's personality shown built up and the appointed time (paras 1-4), but unfortunately, they did not clarify vocabulary development.

\section{b. Writing}

Different from speaking, writing more likely enables the individuals to communicate indirectly through written form. Formerly, individuals only use pens and pieces of paper to communicate with each other. Nevertheless, lately, it is easier with digital virtues present, which enable to connect even if it is far away. Relate to it, Instagram can properly to backing the purpose of writing mainly to expressing an opinion. Either communicative purpose andlong-distance service are one of Instagram value merit. Through Instagram, the users can text message privately or publicly and post whether for local and global view scale.

In line with this, Al-Ali (2014) explained that Instagram offers many advantages in its mobility and accessibility, which are suitable with continuous language exposure (as cited in Akhiar et al., 2017, p.64). Correspondingly, Kurniawan and Kastuhandayani (2016) exposed that Instagram's advantages are more overt and proved Instagram is an enjoyable and 
Rasyiid, Maulina, Resueňo, Nasrullah, and Rusli.

Tell: Teaching of English Language and Literature Journal

Vol. 9, No.2, September 2021, Doi: http://dx.doi.org/10.30651/tell.v9i2.9482

innovative learning tool alongside student's creativeness building in writing. Furthermore, the students are more active and are motivated to learning more. Even so, the researchers did not put any explanation about the Instagram effect on writing vocabulary.

\section{c. Reading}

Reading is one technique to receive written information from books, journals, articles, and other written messages. Reading often ends up writing in order to give and take the information. When someone intends to understand a piece of written information, they must read first, and without reading, the information would not be understood. Consequently, reading comprehension is highly needed for mastery. For this purpose, Instagram is so superfine to use as learning media because 1) Instagram is one platform that provides uncountable reading in various forms such as someone's post, random quotations, and subtitled video available in multiple languages, mainly English. 2) Instagram provides many reading passages for the armature to advance level. 3) The reading text mostly makes in an attractive shape. 4) Reading text mostly posts by people from all over the world. 5)The reading text not only focuses on one topic. 6) Enable the user to read and repeat someone chatting and commenting.

Creating book trailers and sharing reading recommendations are a couple of activities that recommended applying. Creating book trailers is an activity created by Ferlazzo (2019) to obliged the students to make a video for around fifteen seconds to gain their friends' intention and see how much "like" they got. The video their post has to contain the title, author, and most importantly, they must give their favorite quote based on the book. Similarly, sharing reading recommendations was proposed by Hudson to necessitated the students to made a snap about their favorite book review for five sentences and other classmates write down their opinion and comment (Ferlazzo, 2019; Hudson, 2018, as cited in Suryantari \& Priyanka, 2018, p.300), but they did not offer an additional explanation about some cases when the students find out new complex vocabulary.

\section{d. Listening}

Listening is one technique to receive spoken information from speakers directly or from media (e.g., radio, tape recorder, television, and other media). Listening often ends up speaking to give and take the information. Listening is often used to understand the sound that comes from the speakers or any other sound producers. Same as reading, listening is very crucial to mastery for understanding the information given. As well as reading, Instagram is appropriated to assist the students in improving their listening skills.

Moreover, some steps possibly take to increase students listening skills. First, the students must determine their needs alongside their level (e.g., primary, intermediate, and advanced level). Second, the students commence looking for some pages related to their needs. Next, set all the notifications to remind if there is a new notification. Last, repeat all the steps as much as possible.

As well as the statement above, Hudson suggested an activity that obliged the students to answer the teacher question based on the certain video, which can be a short song, movie chunk, or short conversation (as cited in Suryantari \& Priyana, 2018, p.300), but they did not offer what happened next when the students find some vocabulary which hard to get. Thus, those examples can improve listening skills and splendid study much more to gain other splendid findings. 
Rasyiid, Maulina, Resueňo, Nasrullah, and Rusli.

Tell: Teaching of English Language and Literature Journal

Vol. 9, No.2, September 2021, Doi: http://dx.doi.org/10.30651/tell.v9i2.9482

\section{e. Grammar and Vocabulary}

In order to improve English skills, grammar and vocabulary mastery are essential to understand to make a good vibe in the learning process. When someone has enough capability in mastering grammar and vocabulary, they will reduce the possibility of making any mistakes. Grammar is the rule of constructing a good sentence and serving as an explanatory unit of a sentence. Therefore, when someone arranges their thought using grammar, they would sound more precise and accurate so the receiver can avoid misunderstanding. Meanwhile, vocabulary is the smallest unit in a language that serves as the substance to create a language. Therefore, it can be identified that either grammar or vocabulary has one unity that cannot be separated.

There are two kinds of perception in describing grammar and vocabulary. The first is the people who think grammar and vocabulary did not classify as the branch of English skill, and the second is the people who believe it does. The impact of this perception leads EFL learners to become two categories, which is the people who consider both grammar and vocabulary are crucial to know before start learning another English skill and also people who consider both grammar and vocabulary just a trivial matter and get less intention rather than speaking, writing, reading, and listening terms. In the end, the first category has excellent grammar and vocabulary insight before continuing to improving their English skills, and the second category has tremendous English skill mastery but has grammatical and vocabulary errors.

Grammar and vocabulary mastery is also regarded as sub-skill conjunct four primary English skills: speaking, writing, reading, and listening. It happens because when using grammar, some people can address their idea better, both pass through orally and written alongside improving capability in collecting the idea through listening and reading. As well as grammar, vocabulary also has a crucial role in making a good sentence. Generally, ideas make as an abstract thing in human thought. So, vocabulary could make it become concreate and finally make the idea understandable.

As an example, there is a small presentation in front of the class, and the material must be present is about vacation experience. Then, the teacher instructs all of the students to make a paper before the presentation is held. Afterward, the teacher explains that the paper must be present one by one, and the others students have to listen to the speaker and try to conclude what the speaker is talking about. In short, the teacher wants to evaluate the students' skills, including writing, reading, speaking, listening, and grammar and vocabulary mastery. So, the primary reason for the presentation is to ascertain how the correlation between grammar and vocabulary towards four English skills.

To begin with, in writing the paper, the students have to use the simple past tense, which means all the verbs have to change into a second verb like the word go become went. Obliquely, all English skills improve at the same time. It starts when the students write the paper using the second verb. During the presentation, the speaker will read and deliver the material within a simple past tense, and then the rest will listen to the presenter before concluding the topic. In conclusion, this example is enough evidence to prove that grammar and vocabulary highly affect the four English skills.

Furthermore, Cahyono and Widiati stated that vocabulary comprehension needs to develop because it can permit the students to understand numerous words well and then apply them to communicate with others. Likewise, Intaraprasert also mentioned three goals of learning vocabulary: obtaining new words alongside the meaning for each word, memorizing the words, and increasing the number of personal vocabulary comprehension ( as cited in Asyiah, 2017 p. 296). Based on the statements above, it can be seen that vocabulary has a massive impact on learning and teaching English. People will retain challenges to develop and enhance their skills unless they enrich their vocabulary. 
Rasyiid, Maulina, Resueňo, Nasrullah, and Rusli.

Tell: Teaching of English Language and Literature Journal

Vol. 9, No.2, September 2021, Doi: http://dx.doi.org/10.30651/tell.v9i2.9482

Above all, Instagram provides massive numbers of material about grammar and vocabulary. Both grammar and vocabulary are the most common material which appears on most Instagram English pages, and almost all the materials talking about grammar and vocabulary. The materials usually discuss errors and mistakes, tips and tricks, and how to use them daily. The materials usually shape as videos and photos that can be found on every page related to English. For instance, there is a page, namely KampusInggriLC. Indonesian English learners created this page to adapt with grammar and vocabulary in the native context, and this page often sends many videos and photos in a week. In general, the content has much insight, and it assists the followers in learning English. In line with it, there is also a page, namely gurukumrd, created by an outsider, namely Mister Dennis or well known as Mr. D. Again, he always makes some content about the comparison between Indonesian and native context. Then, he gladly makes short videos to discuss it. Next, he inserts many clarifications for every word or phrase he compared. For all of those reasons above, Instagram still has much potential to find and significantly develop grammar and vocabulary comprehension.

\section{Instagram Strength and Weakness as Learning Tool}

In this part, five articles are selected to see whether or not Instagram is appropriate as a learning tool. In this case, the article focuses on English skills and another good journal related to Instagram as a learning and teaching media to gain sufficient evidence whether or not Instagram is a new integrated learning media.

Table 1

Descriptive Details of Articles

\begin{tabular}{|c|c|c|c|c|c|c|}
\hline No & Author \& Title & Focus & Study Purpose & Result & Strength & Weakness \\
\hline 1 & $\begin{array}{l}\text { Suryantari and } \\
\text { Priyana. } \\
\text { (2018). } \\
\text { Exploring way } \\
\text { of using } \\
\text { Facebook and } \\
\text { Instagram in } \\
\text { teaching English }\end{array}$ & $\begin{array}{l}\text { Speaking, } \\
\text { Writing } \\
\text { Listening, and } \\
\text { Reading }\end{array}$ & $\begin{array}{l}\text { 1. Find out } \\
\text { opportunity to } \\
\text { improve } \\
\text { teaching } \\
\text { learning } \\
\text { process beyond } \\
\text { the class. } \\
\text { 2. Improve } \\
\text { students' } \\
\text { creativity. } \\
\text { 3. Maintain } \\
\text { student } \\
\text { motivation } \\
\text { 4. Explore } \\
\text { Facebook and } \\
\text { Instagram } \\
\text { possibility as } \\
\text { media to } \\
\text { practice in } \\
\text { teaching } \\
\text { learning } \\
\text { process }\end{array}$ & Positive & $\begin{array}{l}\text { 1. Flexible } \\
\text { design } \\
\text { 2. Joy learning } \\
\text { experience } \\
\text { 3. Innovative }\end{array}$ & Nothing \\
\hline
\end{tabular}


Rasyiid, Maulina, Resueňo, Nasrullah, and Rusli.

Tell: Teaching of English Language and Literature Journal

Vol. 9, No.2, September 2021, Doi: http://dx.doi.org/10.30651/tell.v9i2.9482

\begin{tabular}{|c|c|c|c|c|c|c|}
\hline No & Author \& Title & Focus & Study Purpose & Result & Strength & Weakness \\
\hline 2 & $\begin{array}{l}\text { Kurniwan and } \\
\text { Kastuhandaya } \\
\text { ni. (2016). } \\
\text { Utilizing } \\
\text { Instagram for } \\
\text { engaging } \\
\text { students in their } \\
\text { creative writing }\end{array}$ & Writing & $\begin{array}{l}\text { 1. Find out } \\
\text { potential of } \\
\text { new learning } \\
\text { environment. } \\
\text { 2. Engage the } \\
\text { students in } \\
\text { writing } \\
\text { activity. }\end{array}$ & Positive & $\begin{array}{l}\text { 1. Enjoyable } \\
\text { learning } \\
\text { experience } \\
\text { 2. Innovative } \\
\text { 3. Enable to } \\
\text { maintaining } \\
\text { motivation }\end{array}$ & Nothing \\
\hline 3 & $\begin{array}{l}\text { Romero- } \\
\text { Rodríguez et } \\
\text { al. (2020). Use } \\
\text { of Instagram by } \\
\text { Pre-service } \\
\text { teacher } \\
\text { education: } \\
\text { Smartphone } \\
\text { habits and } \\
\text { dependency } \\
\text { factor }\end{array}$ & $\begin{array}{l}\text { College } \\
\text { Students } \\
\text { Psychology }\end{array}$ & $\begin{array}{l}\text { 1. Analyze } \\
\text { Instagram } \\
\text { usage habits } \\
\text { of future } \\
\text { primary } \\
\text { school } \\
\text { teacher. } \\
\text { 2. Determine the } \\
\text { influence of } \\
\text { socidemograp } \\
\text { hic factors on } \\
\text { intensive } \\
\text { Instagram use } \\
\text { and } \\
\text { Smartphone } \\
\text { addition }\end{array}$ & Negative & Nothing & $\begin{array}{l}\text { Potentially } \\
\text { addictive } \\
\text { behavior }\end{array}$ \\
\hline 4 & $\begin{array}{l}\text { Qisthi and } \\
\text { Arifani (2020). } \\
\text { The application } \\
\text { of project based } \\
\text { learning via } \\
\text { Instagram to } \\
\text { improve EFL } \\
\text { Students } \\
\text { speaking skill }\end{array}$ & Speaking & $\begin{array}{l}\text { Figure out } \\
\text { impact of } \\
\text { Instagram usage } \\
\text { to improve } \\
\text { speaking skill } \\
\text { through project } \\
\text { based learning. }\end{array}$ & Positive & $\begin{array}{l}\text { 1. Fun } \\
\text { 2. Effective }\end{array}$ & Nothing \\
\hline 5 & $\begin{array}{l}\text { Al-Garawi. } \\
\text { (2019) } \\
\text { Investigating the } \\
\text { use of Instagram } \\
\text { as a MALL tool: } \\
\text { The case of al- } \\
\text { imam univesity } \\
\text { EFL students }\end{array}$ & $\begin{array}{l}\text { Instagram } \\
\text { usage for } \\
\text { educational } \\
\text { purpose }\end{array}$ & $\begin{array}{l}\text { 1. Investigate the } \\
\text { benefit of } \\
\text { using } \\
\text { Instagram as a } \\
\text { MALL tool. } \\
\text { 2. Reveal the } \\
\text { challenge of } \\
\text { using } \\
\text { Instagram in } \\
\text { English } \\
\text { language } \\
\text { learning. }\end{array}$ & Neutral & $\begin{array}{l}\text { 1. Multifuncti } \\
\text { on } \\
\text { 2. Enjoyable }\end{array}$ & $\begin{array}{l}\text { 1. Distractin } \\
\mathrm{g} \\
\text { attention } \\
\text { 2. Cost } \\
\text { internet } \\
\text { access. }\end{array}$ \\
\hline
\end{tabular}


Rasyiid, Maulina, Resueňo, Nasrullah, and Rusli.

Tell: Teaching of English Language and Literature Journal

Vol. 9, No.2, September 2021, Doi: http://dx.doi.org/10.30651/tell.v9i2.9482

The first of the articles is by Suryantari and Priyana (2018). The researchers focus on four English skills such as speaking, writing, reading, and listening. Moreover, they intend to explore any possibility of Instagram usage in the educational field and observe the student's perception toward it. In the end, the result of the paper indicated positive and proper to use as learning media and another educational purpose. In addition, the researchers assumed that Instagram has a Flexible design that can make the students enjoy the new and innovative learning experience.

The second of the articles is by Kurniwan and Kastuhandayani (2016). The researchers focus on students writing skill development. Like the first researchers, they intend to find Instagram potential as a new learning tool and writing new engagement. In the end, the result of the paper indicated positive and proper to use as learning media. Moreover, the researchers assumed that Instagram is an enjoyable learning media that can retain students' writing motivation.

A third of the articles are by Romero-Rodríguez et al. (2020). The researchers focus on college student's psychology, particularly Pre-service teacher education. Moreover, the researcher wants to analyze the Instagram usage habits of future primary school teachers and its influence of sociodemographic factors on intensive Instagram use and smartphones. In the end, the paper shows the negative impact of using Instagram as a learning medium. In addition, the calculation and percentages show that Instagram potentially causes addictive behavior.

The next of articles is by Qisthi and Arifani (2020). The researchers focus on students speaking skills. Moreover, they intend to figure out the impact of Instagram usage to improve speaking skills through project-based learning. Again, the paper has shown positive indications and reaffirming that learning through Instagram is fun and effective.

The last of the articles is by Al-Garawi (2019). The researcher intends to be unsure whether or not Instagram work for educational purposes. Furthermore, the research also wants to investigate the benefit of using Instagram as a MALL and reveal the challenge of using Instagram in English language learning. As a result, the paper indicated neutral. It is because the points to consider oddly balance. It could not be denied that Instagram is a multifunction media that can produce enjoyable learning situations. Nevertheless, on the other hand, the weakness is not a trivial matter because if the students are distracted, they will not focus on the material from the teacher. Therefore, neutral is the better option unless the weakness can reduce.

\section{Student Learning Strategy to Learn Vocabulary using Instagram}

Based on some points above, the writer considers making a learning strategy to learn vocabulary that Instagram mediates. Learning strategy is a couple of steps that apply by the student to absorb specific material effectively. Learning strategy consists of several processes to optimize the process of learning itself. Learning strategy also determines whether or not a learning goal would be accomplished. Likewise, Miarso asserted that a learning strategy is a holistic approach to the learning system situation, which is in the form of general guidelines and a framework of activities to achieve the general purposes of learning and are elaborated from the view of certain philosophies and or learning theories (as cited in Sitorus et al., 2019, p. 454).

Several steps highly recommend to apply when learning vocabulary via Instagram based on authors of this recent conceptual research as follows.

1. Go directly to the searching menu, then type "English Vocabulary." In this step, there will be a great selection of pages to click and follow. So, be sure to follow a page based on your need. 
Rasyiid, Maulina, Resueňo, Nasrullah, and Rusli.

Tell: Teaching of English Language and Literature Journal

Vol. 9, No.2, September 2021, Doi: http://dx.doi.org/10.30651/tell.v9i2.9482

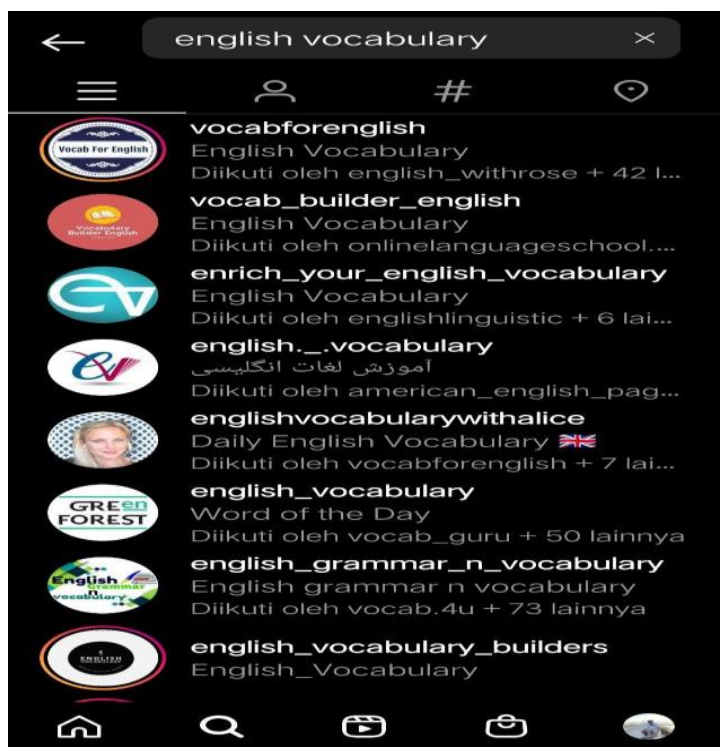

Figure 1. Searching Menu Appearance

2. Enter the main page. In this step, you have to ensure the material especially level and content material. Then, if it fixed enough, click "follow" and dont forget to activing the notifications so you can immediately know if there is a new post.

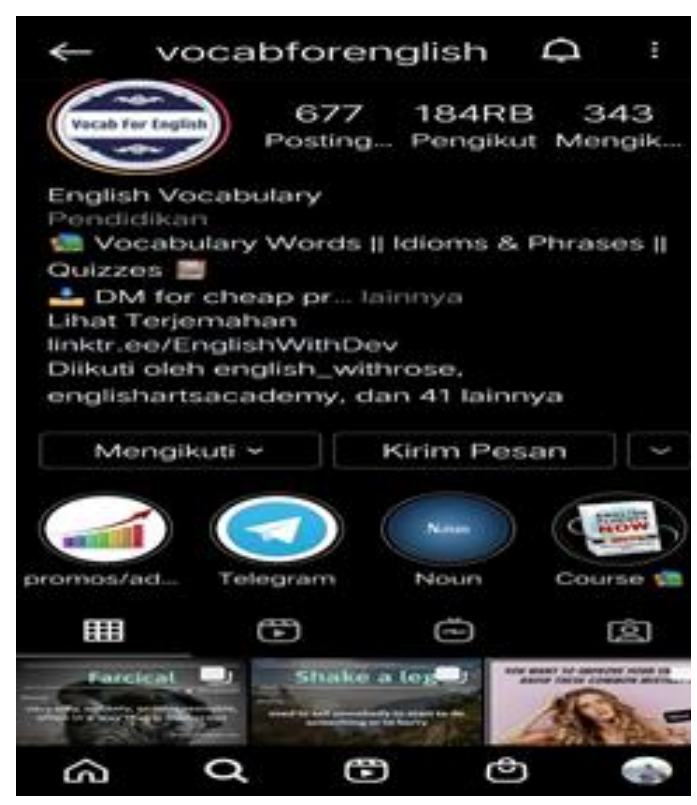

Figure 2. Main Page and Notification Options 
Rasyiid, Maulina, Resueňo, Nasrullah, and Rusli.

Tell: Teaching of English Language and Literature Journal

Vol. 9, No.2, September 2021, Doi: http://dx.doi.org/10.30651/tell.v9i2.9482

3. Afterwards, click material that you interest on. In this step, the user freely to choose the material. Generally, the materials are formed as linked photo and short video. The material also equipped with explaination, pronountiation and example. In addition, sometimes the photos often linked with quiz so the users can try to answer it through commet colomn.
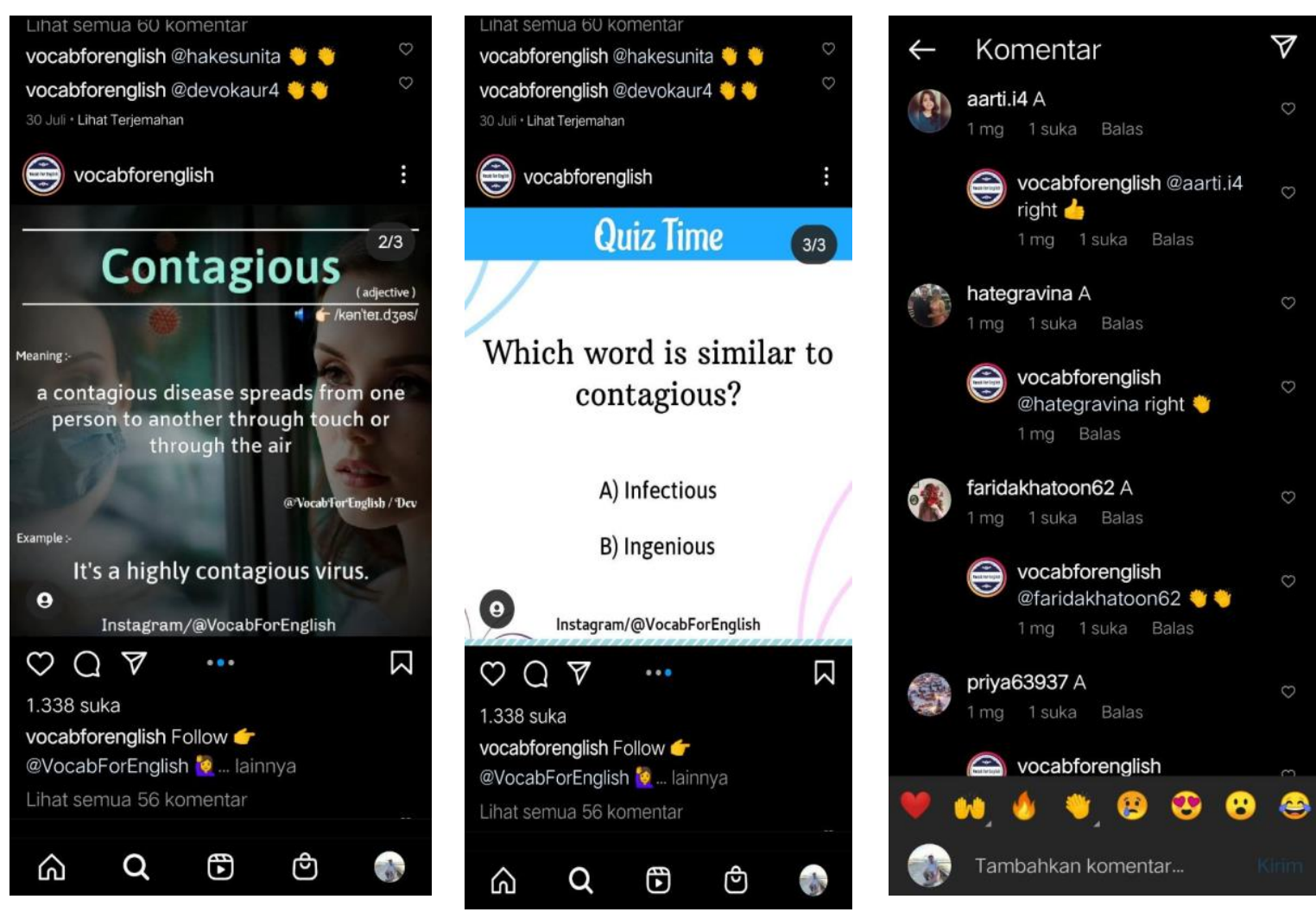

Figure 3. Material, Quiz, and Followers' Reply

4. If you do not have enough time to spend, you can save the material to read later. You can click 'save to collection' to save the material. The saved material will hint white and there will appear a sentence said "saved".

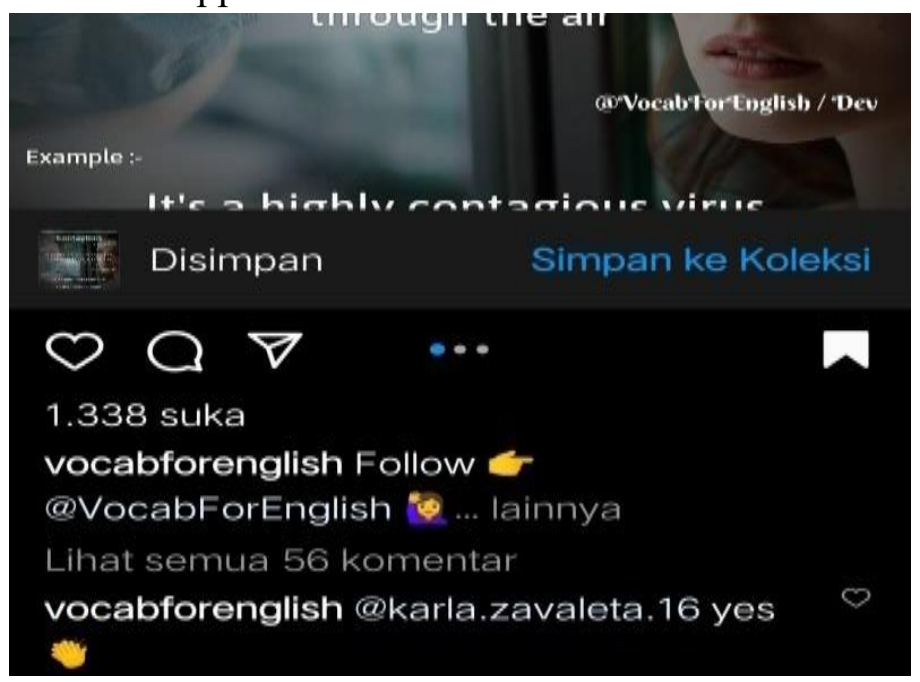

Figure 4. Saving the Material 
Rasyiid, Maulina, Resueňo, Nasrullah, and Rusli.

Tell: Teaching of English Language and Literature Journal

Vol. 9, No.2, September 2021, Doi: http://dx.doi.org/10.30651/tell.v9i2.9482

5. Open the saved material. First, go to your main account appereance then click treeple lines on upper right side. after that, click "save". Afterwards, open the "all post" search your current material.

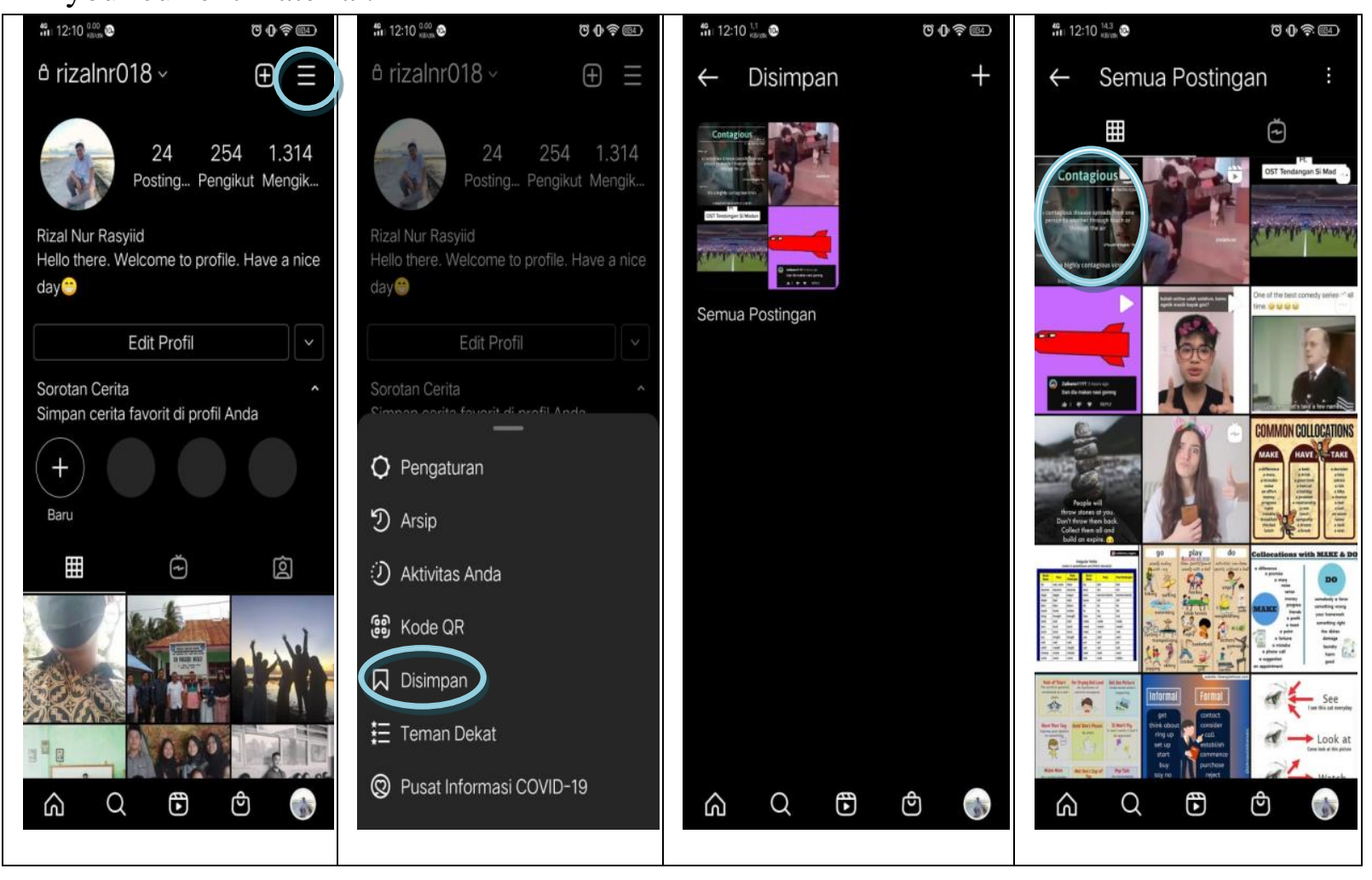

Figure 5. Opening the Saved Material

As the steps above, that is the simple steps for learning vocabulary via Instagram. However, there are still some explanations did not discuss clearly. User's needs are different, and it commonly classifies by their level and purpose. The level refers to how the learners' level of knowledge is whether beginner, basic, intermediate, advance, or even native. Besides, the purpose also refers to what the material wants for, either speaking or writing, formal or non-formal context, etc. Both of these aspects are the point that has to fill so the learning process can be effective. When the users follow the page and activity the notification, the material will show on our veranda. Therefore, it must be established to make the program stimulus show the material based on the need.

In addition, the material form is not just in picture form but also in the video. Generally, the edited photo engages with explanation, pronunciation, and also an example. Moreover, one post usually attached more than one picture for picture form and is often added with a short quiz. So it is used to make it the learners easy to understand the material. Besides, video form is almost identical unless video form directly shows the users how the pronunciation is and sometimes adds with song.

Furthermore, the "saved material" has many advantages, but most people have known about the permanent save the file. This feature enables the users to keep the material as long as they want, and also, the material will never be deleted unless the "save hint" is released. Likewise, the material cannot be deleted when we change our device. 
Rasyiid, Maulina, Resueňo, Nasrullah, and Rusli.

Tell: Teaching of English Language and Literature Journal

Vol. 9, No.2, September 2021, Doi: http://dx.doi.org/10.30651/tell.v9i2.9482

Nevertheless, users must show gratitude to like and help share the content with other people to appraise the creator's hard work. Those are the sample that is Instagram could be a great and effective learning medium.

\section{Conclusion}

The review of the impact of Instagram on educational purposes, particularly in learning English, provided some insightful information in this study. The authors conclude that Instagram is a splendid social media that pledged a myriad of potential to develop. Instagram is helpful to support EFL learners in learning English, especially in learning English vocabulary. Even if it seems trivial, Instagram can cope with the most common students' vocabulary errors, such as miss-context words, spelling and pronunciation errors, and less vocabulary understanding. Nevertheless, this study is simple to research that only relies on a couple of journals without any direct action by the writers. Therefore, the authors believe that Instagram is the best problem solving that can use in learning English, particularly in learning English vocabulary, and it is one of the integrated learning media that all people around the world can use.

\section{References}

Al-Ali, S. (2014), Embracing the selfie craze: Exploring the possible use of instagram as a language mlearning tool. Issuses and Trends in Educational Technology, 2(2).

Al-Garawi, A. Y. A. (2019). Investigating the use of Instagram as a mall tool: The case of alimam university efl students.

Ahmadinejad, B., \& Asli, H.N. (2017). E-business through social media: A quantitative survey (case study: Instagram. International Journal of Management, Accounting and Economics, 4(1).

Aloraini, N. (2018). Investigating instagram as an efl learning tool. Arab World English Journal (AWEJ), 4, 174-184.

Arceneaux, P.C., \& Dinu. (2018). The social mediated age of information: Tweeter and instagram as tools for information dissemination in higher education. SAGE, 20(11), 4155-4176.

Asyiah, D.N. (2017). The vocabulary teaching and vocabulary learning: Perception, strategies, and influences on students vocabulary mastery. Jurnal Bahasa Lingua Scientia, 9(2).

Cahyono, Bambang, Y.,\& Widiati, U. (2008). The teaching of EFL vocabulary in Indonesian context: The state of the art. TEFLIN Journal, 19(1).

Debata, P. K. (2013). The improtance of grammar in english language teaching a reassessment, 13(5). www.languageinindia.com.

Douglas, N.K.M., Scholz, M., Myers, M. A., Rae, S.M., Elmansouri, A., Hall, S., \& Border, S. (2019). Reviewing the role of Instagram in education: Can a photo sharing application deliver benefits to medical and dental anatomy education?. Medical Science Educator.

Ekinci, E. (2020). Mobile assisted language age learning (mall) as a foreign language aid: A literature review. Pearson Journal of Social Sciences \& Humanities, 5(9). https://www.pearsonjournal.com/.

Elarsan, A. (2019). Instagram as an education platform for efl learners. The Turkish Online Journal of Educational Technology, 18 (3).

Handayani, F. (Eds). (2016). Proceeding of the 4th International Seminar on English Language and Teaching. ISELT-4. 
Rasyiid, Maulina, Resueňo, Nasrullah, and Rusli.

Tell: Teaching of English Language and Literature Journal

Vol. 9, No.2, September 2021, Doi: http://dx.doi.org/10.30651/tell.v9i2.9482

Huang, Y., \& Su, S. (2018). Motives for instagram use and topics of interest among young adoult. $M D P I$.

Hudson, H. (2013).10 ways to use Instagram in the classroom. [Online]. Retrieved fromhttp://www.weareteachers.com/comunity/blogs/

Jiang, S., \& Ngien, Annabel. (2020). The effect of instagram use, social comparison, and selfestee, on social anxiety: A survey study in singapore. SAGE.

Kohli, A.L. (1984).Techniques of Teaching English. Delhi: Dhanpat Rai \&Sons.

Kurniawan, A., \& Kastuhandani, L. A. (2016). Utilizing instagram for engaging students in thier creative writing. Indonesia Technology Enhanced Language Learning.

Lilia, K., \& Gulnara, G. (eds). (2016). 9th International Conference of Education. Library. https://dl.acm.org/citation.cfm2id=1166324\&picked=prox.

Maulina, Noni, N., \&Basri, M. (2019).WhatsApp audio and video chat-based in stimulating students' self-confidence and motivation to speak English. Asian EFL Journal, 23(6.3), 181-203.

Maulina, Noni, N., \&Basri, M. (2020).Basic Speaking: WhatsApp-Based Daily Conversation. Deepublish.

Maulina, Geelan, D., Basri, M., \& Noni, N. (2021).Constructing WhatsApp-based speaking instructional material (WABSIM) for EFL teaching and learning: A need analysis. Asian EFL Journal,28(1.2), 89-110.

Miarso, Y. (2009).Menyemai Benih Teknologi Pendidikan Jakarta.Kencana Prenada Media Group.

Pujiati, H., Zahra., \& Tamela, E. (2019). The use of instagram to increase students' motivation and students' competence in learning english. Advances in Social Science, Education and Humanities Research, 335.

Qisthi, N., \& Arifani, Y. (2020). The application of project based learning via Instagram to improve efl students speaking skill.

Richard, J.C. and Renandya, W.A. (2002). Methodology in Language Teaching an Anthology of Current Practice. Cambridge University Press.

Romero-Rodríguez, J., Rodríguez-jiménez, C., Navas-Pajero, M.R ., Marín-Marín., \& Gómez- Garcia, G. (2020). Use of instagram by pre-service teacher education: Smartphone habits and dependency factors. MDPI.

Rozgonjuk, D., Sindermann, C., Elhai, J. D., \& Montag, C. (2020). Fear of missing out (Fomo) and social media's impact on daily-life and productivity at work: Do whatsapp, facebook, instagram, and shapchat use disorder mediate that association. ELSEVIER. www.elsevieer.com/locate/addictbeh.

Saputra, U. R., Maulina, M., Nasrullah, R., \& Sakkir, G. (2021). Students' Sentence Errors on WhatsApp Daily Status: A Literature Review. Celebes Journal of Language Studies, 1(1), 23-31. Retrieved fromhttp://www.harpressid.com/index.php/CJLS/article/view/31

Sheldon, P. \& Bryant, K. (2015). Instagram: Motives for its use and relationship to narcissism and contectual age. ELSEVIER. www.elsevieer.com/locate/comphumbeh.

Sitorus, H., Nugrahadi, E. W., \& Budiarta, K. (2019). The effect of learning strategy and thinking ability on the students' learning outcomes in economics subject of xi social students in senior high school state 1 in pematang siantar. Budapest International Research and Critics in Linguistics and Education (BirLE) Journal, 2(4), 451-460. 
Rasyiid, Maulina, Resueňo, Nasrullah, and Rusli.

Tell: Teaching of English Language and Literature Journal

Vol. 9, No.2, September 2021, Doi: http://dx.doi.org/10.30651/tell.v9i2.9482

Stojanovíc, D., Bogdanovíc, Z., Despotovíc-Zrakíc, M., Naumovíc, T., \& Radenkovíc. (2019). An approach to using instagram in secondarye education.

Sukmawati, N.N., \& Sesriyani, L. (2019). Analisis penggunaan instagram sebagai media pembelajaran bahasa inggris pada program studi pendididikan ekonomi. Jurnal Pendidikan, Hukum, dan Bisnis, 4(1).

Suryantari, H. \& Priyana, J. (2018). Exploring ways of using facebook and instagram in teaching english. Advances in Social Science, Education and Humanities Research, 165.

Ting, H., Ming, W.W.P., Run, E.C.D., \& Choo, S.L.Y. (2015). Belief about use of instagram: An exploratory study. International Journal of Bussiness and Innovation, 2(2).

Webb, S., \&Kagimoto, E. (2009).The effects of vocabulary learning on collocation and meaning. TesolQuarterl y, 43(1), 55-77.

Yudhiantara, R.A., \& Nuryantini, A. Y. (2018). Instagram-assisted language learning in islamic higher education: Toward online collaboration. JEELS, 5(2). 